Original Research Paper

\title{
Peningkatan Hasil Belajar Peserta Didik dengan Menggunakan Media Animasi dengan Pendekatan Submikroskopik Pada Pembelajaran Ikatan Kimia di Kelas X IPA
}

\author{
Nurlaila $^{1^{*}}$ \\ ${ }^{1}$ Sekolah Menengah Atas Negeri 1 Mataram, Mataram Nusa Tenggara Barat, Indonesia
}

*Corresponding Author:

Nurlaila, Sekolah

Menengah Atas Negeri 1

Mataram, Mataram Nusa

Tenggara Barat, Indonesia.

Email:

nurlailanona@gmail.com

\begin{abstract}
Abstrak: Penelitian ini bertujuan mengetahui sejauh mana keberhasilan pembelajaran ikatan kimia dengan menggunakan media animasi dengan pendekatan submikroskopik dilatarbelakangi pembelajaran ikatan kimia merupakan pembelajaran yang abstrak sehingga tidak menutup kemungkinan peserta didik akan mengalami kesulitan dalam memahami materi tersebut. Untuk membantu mengatasi kesulitan memahami konsep ikatan kimia perlu media pembelajaran yang menggabungkan ketiga aspek dalam pembelajaran kimia yaitu makro, mikro dan simbol, media yang dipakai adalah media animasi dengan pendekatan submikrroskopis. Subjek penelitian peserta didik kelas X IPA-3 SMA Negeri 2 Selong. Dari hasil penelitian dapat disimpulkan penggunaan media pembelajaran dengan pendekatan submikroskopis dapat meningkatkan pemahaman tetntang ikatan kimia, hal ini dilihat dari hasil tes menunjukkan bahwa terjadi peningkatan hasil belajar ikatan kimia.
\end{abstract}

Kata Kunci: media animasi, submikroskopik dan hasil belajar

\section{Pendahuluan}

Pemerintah mempunyai r $\begin{array}{r}\text { fungsi } \\ \text { menyelenggarakan suatu sistem pendidikan }\end{array}$
nasional sebagaimana tercantum dalam Undang-
Undang Nomor 20 Tahun 2003 tentang Sistem
Pendidikan Nasional "bahwa pendidikan adalah
usaha sadar dan terencana untuk mewujudkan
susana belajar dan proses pembelajaran agar peserta
didik secara aktif mengembangkan potensi dirinya"
berarti pendidikan itu harus berorientasi kepada
peserta didik (student active learning).
Proses dan hasil pembelajaran kimia di Sekolah Menengah Atas akhir-akhir ini mendapat banyak kritik. Menurut Tim Pengembang Ilmu Pendidikan FIP-UPI (2007) dalam Ratna 2012 mengatakan sejumlah kritik terarah pada kegiatan belajar mengajar yang berpusat pada guru (teacher centered). Materi disampaikan dengan ceramah sehingga pengetahuan berupa fakta, konsep, prinsip, hukum, teori, dan prosedur kimia disampaikan oleh guru tanpa menstimulasi peserta didik untuk berpikir atau bernalar. Berbagai kajian menunjukkan bahwa pembelajaran seperti ini kurang efektif bagi peserta didik sehingga diperlukan adanya modifikasi atau variasi dalam proses pembelajaran.

Secara umum, pengajaran dan pembelajaran terbatas pada tingkat repsrentasi makroskopis dan simbolis. Banyak guru sekolah tinggi cenderung hanya menggunakan tingkat makroskopis dan tingkat simbolis. Pengembangan pendekatan belajar dan mengajar kimia lebih ditekankan pada tiga level representasi, yaitu makroskopik, submikroskopik, dan simbolik (Farida, 2010). Tingkat makroskopis yang bersifat nyata dan mengandung bahan kimia yang kasat mata dan nyata. Tingkat submikroskopis juga nyata tetapi tidak kasat mata yang terdiri dari tingkat partikulat yang dapat digunakan untuk menjelaskan pergerakan elektron, molekul, partikel atau atom. Yang terakhir adalah tingkat simbolik yang terdiri dari berbagai jenis representasi gambar maupun aljabar (Johnstone 1982). Di antara ketiga level ilmu kimia tersebut penjelasan level submikroskopik belum mendapat perhatian dalam pembelajaran di kelas (Sopandi dkk, 2008). Pada umumnya pembelajaran kimia yang terjadi saat ini hanya membatasi pada dua level representasi, yaitu makroskopik dan simbolik. Level berpikir 
mikroskopik dipelajari terpisah dari dua tingkat berpikir lainnya, sehingga peserta didik cenderung hanya menghafalkan representasi sub mikroskopik dan simbolik yang bersifat abstrak (dalam bentuk deskripsi kata-kata) akibatnya tidak mampu untuk membayangkan bagaimana proses dan struktur dari suatu zat yang mengalami reaksi (Rosita, 2013).

Kurikulum 2013 dikembangkan salah satunya berbasis kompetensi dirancang untuk memberikan pengalaman belajar seluas-luasnya untuk peserta didik dengan pembelajaran yang berpusat pada peserta didik bukan berpusat pada guru. Salah satu komptensi yang harus dicapai peserta didik adalah kompetensi pengetahuan 3.5 tentang Membandingkan ikatan ion, ikatan kovalen, ikatan kovalen koordinasi, dan ikatan logam serta kaitannya dengan sifat zat. Materi ikatan kimia, materi yang mempelajari cara atom bergabung membentuk molekul. Secara garis besar ikatan kimia dibagi menjadi dua kategori yaitu ikatan ion dan ikatan kovalen.

Dasar teori untuk mempelajari kompetensi dasar ini adalah struktur atom, konfigurasi electron, electron valensi dan struktur Lewis. Semuanya itu bersifat abstrak, sehingga tidak menutup kemungkinan peserta didik akan mengalami kesulitan dalam memahaminya. Ikatan kimia merupakan salah satu materi yang mempelajari halhal yang mikroskopik. Hal ini membuat peserta didik kurang paham dan cenderung hanya menghafal. Untuk membantu mengatasi kesulitan memahami konsep-konsep tersebut diperlukan media pembelajaran yang yang menggabungkan ketiga aspek dalam pembelajaran kimia, yaitu makro, mikro dan symbol yang dirasa sangat perlu dalam menunjang pembelajaran kimia di sekolah.

Kurikulum kimia harus bertujuan memberikan bimbingan kepada peserta didik untuk menggunakan multi representasi, baik secara verbal maupun visual agar dapat mengembangkan kemampuan representasinya. Animasi dan simulasi secara visual membantu peserta didik memahami konsep yang sulit tentang sistem kimia yang kompleks seperti molekul dan reaksi (Kozma dan Russell, 2005). Akan tetapi, pembelajaran yang menggunakan animasi dan visualisasi harus disertai dengan penjelasan dan diskusi untuk menghindari kesalahan peserta didik dalam merepresentasikan visualisasi tersebut (Falvo, 2008).

Media visual adalah gambar. Animasi dalam bidang multimedia biasanya berupa gambar (still image) yang kemudian disusun menjadi sebuah runtutan gambar yang jika disatukan akan terlihat bergerak. Prinsip dasar animasi adalah membuat obyek yang seolah-olah bergerak sebagai satu kesatuan yang utuh. Meskipun pada awalnya animasi dibuat pada satu bagian tertentu secara terpisah yang kemudian disatukan kembali untuk mendapatkan pergerakan sempurna.

Peserta didik diharapkan dapat memahami dengan baik materi ikatan kimia jika peserta didik dapat membangun imajinasinya. Visualisasi molekuler berbasis computer animasi yang diintergrasikan dalam pembelajaran dapat membantu peserta didik mengembangkan imajunasinya sehingga dapat meningkatkan kemampuan representasi. Visualisasi Visualisasi level submikroskopik membantu peserta didik memahami apa yang terjadi pada partikel-partikel dalam pembentukan ikatan kimia dalam hal ini pembentukan ikatan ion dan ikatan kovalen. Representasi submikroskopik yang dilihat oleh peserta didik dapat membantu peserta didik menjelaskan cara pembentukan ikatan ion dan ikatan kovalen yang terjadi antara atom atom sehingga memudahkan peserta didik menentukan sifat kepolaran senyawa.

Berdasarkan uraian di atas, maka penulis akan melakukan penelitian dengan judul "Peningkatan hasil belajar peserta didik dengan menggunakan media animasi dengan pendekatan Submikroskopik pada Pembelajaran Ikatan kimia pada kelas X IPA".

\section{Metode Pelaksanaan}

Penelitian ini merupakan penelitian eksperimen yaitu melakukan kegiatan yang direncanakan dan dilaksanakan oleh peneliti untuk mengumpulkan bukti-bukti yang ada, sedangkan pendekatan yang digunakan adalah pendekatan kuantitatif. Waktu yang digunakan dalam penelitian untuk mengambil data adalah bulan Oktober semester ganjil Tahun Pelajaran 2016/2017. Penelitian ini dilaksanakan di SMA Negeri 2 Selong pada kelas X IPA-3, sebanyak 38 orang peserta didik yang terdiri dari 16 orang peserta didik laki-laki dan 22 orang peserta didik wanita. Variabel bebas adalah media animasi dengan pendekatan submikroskopis, variabel terikat adalah hasil belajar. Analisis yang digunakan yaitu 
menghitung hasil belajar siswa dan menghitung ketuntasan belajar klasikal.

1. Menghitung hasil belajar siswa.

Hasil belajar siswa dapat dihitung dengan rumus sebagai berikut:

$$
\text { Nilai }=\frac{\Sigma \text { jawaban benar }}{\Sigma \text { jawabantotal soal }} \times 100
$$

2. Menghitung ketuntasan belajar klasikal Ketuntasan belajar klasikal dihitung dengan rumus:

Tuntas klasikal $=\frac{N 1}{N} \times 100 \%$

$\Sigma \mathrm{N} 1=$ jumlah peserta didik tuntas belajar secara individual (nilai 75 keatas)

$\mathrm{N}$ = banyaknya peserta didik

\section{Hasil Dan Pembahasan}

\section{Aktifitas Belajar Peserta Didik}

Pembelajaran ikatan kimia yang telah dilaksanakan dengan menggunakan animasi submikroskopis ini memiliki hasil yang sangat baik terhadap keaktifan peserta didik. Keberhasilan dalam pembelajaran salah satunya dipengaruhi oleh keaktifan peserta didik dalam pembelajaran. Aktifitas peserta didik pada saat pembelajaran meningkat dari pembelajaran sebelumnya. Aktivitas belajar yang mengalami peningkatan tersebut dapat diamati selama proses pembelajaran berlangsung. Peserta didik bekerjasama dalam kelompok seperti saling memberikan ide dalam menjawab soal atau ada juga yang menjawab pertanyaan dari anggota dalam kelompoknya dalam membahas soal yang dalam dalam slide mulai dari mereka berdiskusi tentang konfigurasi elektron, electron valensi dan menggambar/menentukan ikatan kimia yang terjadi antara atom-atom dalam membentuk senyawa. Disamping itu peserta didik juga aktif dalam diskusi kelas dalam hal ini aktif dalam bertanya atau menjawab pertanyaan selama diskusi kelas berlangsung.

\section{Pemahaman Peserta didik Terhadap Materi Ikatan Kimia}

Secara umum kegiatan pembelajaran yang dilaksanakan pada materi ikatan kimia menggunakan media animasi submikroskopis dapat meningkatkan pemahaman peserta didik terhadap bagaimana menentukan ikatan kimia suatu senyawa secara lebih kongkret. Selama pembelajaran berlangsung peserta didik mampu membuat konfigurasi eketron dan menghitung elektron valensi unsur dalam senyawa, menyetabilkan suatu atom untuk membentuk suatu ikatan kimia. Peserta didik mampu membentuk ikatan kimia baik ikatan ion dan ikatan kovalen, seperti membuat ikatan antara atom $\mathrm{N}$ dan $\mathrm{H}$ menghasilkan senyawa $\mathrm{NH}_{3}$, arom $\mathrm{Mg}$ dan atom $\mathrm{Cl}$ menghasilkan senyawa $\mathrm{MgCl}_{2}$. Pemahaman peserta didik terhadap ikatan kimia khususnya ikatan kovalen dapat dilihat dari kemampuan peserta didik membuat struktur Lewis, menempatkan elektron sehingga masing-masing atom mampu mencapai konfigurasi elektron stabil dengan 8 elektron. Peserta didik mampu menentukan kemungkinan terbentuknya ikatan rangkap 2 dan ikatan rangkap 3.

Beberapa kelemahan peserta didik dalam membentuk ikatan kovalen dari senyawa yang diberikan adalah ketika diberikan beberapa senyawa yang tidak mengikuti aturan oktet misalnya $\mathrm{BeCl}_{2}$. Unsur $\mathrm{Be}$ yang tidak mencapai oktet menjadikan perdebatan di antara peserta didik dalam kelompok. Penjelasan guru diperlukan untuk senyawa-senyawa yang tidak sesuai dengan aturan oktet.

Peningkatan pemahaman peserta didik dalam mempelajari ikatan ion dapat dilihat dari kemampuan peserta didik dalam berdiskusi bersama menentukan ikatan ion. Peserta didik mampu menentukan jumlah elektron valensi unsur, unsur akan melepaskan electron atau unsur akan menerima electron. Setelah mengetahui unsur yang melepaskan dan unsur yang menerima electron maka peserta didik mampu mendiskusikan senyawa yang terbentuk. Pemahaman peserta didik kemudian dapat dilihat dari kemampuan peserta didik membentuk ikatan ion dan ikatan kovalen dapat dilihat dari nilai hasil ulangan harian peserta didik khususnya soal-soal tentang ikatan kovalen dan ikatan ion mencapai ketuntasan yang diharapkan

\section{Hasil Belajar Peserta Didik}

Pembelajaran dengan menggunakan animasi submikroskopis ditujukan untuk mencapai kompetensi dasar 3.5 dan 4.5 dari standar isi kurikulum 2013 untuk kelas X peminatan MIPA. Pembelajaran dilaksanakan di kelas $\mathrm{X}$ IPA3. Setelah pembelajaran dilaksanakan ulangan untuk 
melihat pemahaman peserta didik tentang pembentukan ikatan kimia dalam hal ini ikatan ion dan ikatan kovalen secara umum hasil belajar peserta didik setelah pembelajaran menggunakan animasi submikroskopis sangat baik. Dari hasil perhitungan terdapat 31 peserta didik pada kelas $X$ IPA 3 mencapai ketuntasan belajar yang ditetapkan yaitu 75 , sedangkan 7 orang peserta didik masih berada dibawah nilai ketuntasan belajar yang ditetapkan. Hal ini ditandai dengan meningkatnya nilai rata-rata hasil belajar, peserta didik 84.7, persentase peserta didik yang tuntas secara klasikal $81.6 \%$

\section{Kesimpulan}

Berdasarkan hasil penelitian dan pembahasan dapat disimpulkan: 1) Pembelajaran menggunakan media pembelajaran animasi submikroskopis untuk memahami pembentukan ikatan kimia dapat meningkatkan aktivitas peserta didik dalam pembelajaran, 2) Pembelajaran menggunakan media pembelajaran animasi submikroskopis untuk memahami pembentukan ikatan kimia dapat meningkatkan pemahaman pemahaman peserta didik terhadap pembentukan ikatan kimia. Hal ini ditandai dengan meningkatnya nilai rata-rata hasil belajar, peserta didik 84.7 , persentase peserta didik yang tuntas secara klasikal $81.6 \%, 3$ ) Penggunaan media pembelajaran animasi submikroskopis secara umum mempermudah guru mengajarkan pembentukan ikatan kimia.

\section{Daftar Pustaka}

Azizah Mashami, Ratna. 2012. Pengembangan Media Dengan Pendekatan Submikroskopis Pada Pembelajaran Multirepresentasi Serta Pengaruhnya Terhadap Kemampuan Representasi dan Ketrampilan Berpikir Kritis Siswa. Tesis. Universitas Mataram.

Chandrasegaran, Treagust dan Mocerino. 2007. Enhancing Students' Use of Multiple Levels of Representation to Describe and Explain Chemical Reactions

Direktorat Pembinaan SMA Direktorat Jenderal Pendidikan Menengah Kementerian Pendidikan dan Kebudayaan. 2014. Pembelajaran Kimia Melalai Pendekatan
Saintifik. Jakarta: Departemen Pendidikan dan kebudayaan.

Departemen Pendidikan Nasional. (2006). Panduan Penyusunan Kurikulum Tingkat Satuan Pendidikan. Jakarta: Pusat Kurikulum Badan Penelitian dan Pengembangan

Falvo, D. (2008). Animations and simulations for teaching and learning molecular chemistry. International Journal of Technology in Teaching and Learning, 4(1), 68-77

Farida, Liliasari, Widyantoro dan Sopandi. 2010. The Importance of Development of Representational Competence in Chemical Problem Solving Using Interactive Multimedia. Proceeding The $4^{\text {th }}$ Internasional Seminar in Science Education

Fitri, Herawati, Rosita, 2012. Pembelajaran Kimia berbasis Multiple Representasi Ditinjau Dari Kemampuan Awal Terhadap Prestasi Belajar Laju Reaksi Siswa SMA Negeri 1 Karanganyar 2011/2012. Universitas Sebelas Maret, Surakarta

Johnstone, A. H. 1982. Macro- and MicroChemistry, School Science Review., 227, No. 64. p. 377-379.

Kozma, R. dan Russell, J. 2005. Students Becoming Chemists: Developing Representational Competence. In JK. Gilbert (Ed), Visualization in Science Education.

Peraturan Menteri Pendidikan dan Kebudayaan Republik Indonesia Nomor 59 Tahun 2014 tentang Kurikulum Sekolah Menengah Atas. 2014. Jakarta: diperbanyak oleh Badan Standar Nasional Pendidikan.

Peraturan Menteri Pendidikan dan Kebudayaan Republik Indonesia Nomor 64 Tahun 2013 tentang Standar Proses Pendidikan Dasar dan Menengah. 2013. Jakarta: diperbanyak oleh Badan Standar Nasional Pendidikan

Sopandi, Rohman, Sukmawati, Yuliani, Nuraeni, Turyani dan Aryani. 2008. Penjelasan Level Mikroskopik dalam Buku Teks kimia. Makalah disajikan pada Seminar Internasional 2 Pendidikan IPA

Departemen Pendidikan Nasional. 2003. Kurikulum berbasis kompetensi. Jakarta. 